\title{
Hydrological controls on patterns of surface, internal and basal motion during three "spring events": Haut Glacier d'Arolla, Switzerland
}

\author{
Douglas MAIR, ${ }^{1}$ IAn WILlis, ${ }^{2}$ Urs H. FISCHER,${ }^{3}$ Bryn HUBBARD,${ }^{4}$ \\ Peter NienOW, ${ }^{5}$ Alun HUBBARD ${ }^{6}$ \\ ${ }^{1}$ Department of Geography and Environment, University of Aberdeen, Elphinstone Road, Aberdeen AB24 3UF, Scotland \\ E-mail:_mair@abdn.ac.uk \\ ${ }^{2}$ Scott Polar Research Institute, Department of Geography, University of Cambridge, Cambridge CB2 3ER, England \\ ${ }^{3}$ Laboratory of Hydraulics, Hydrology and Glaciology, Swiss Federal Institute of Technology, CH-8092 Zürich, Switzerland \\ ${ }^{4}$ Centre for Glaciology, Institute of Geography and Earth Sciences, University of Wales, Aberystwyth ST23 3DB, Wales \\ ${ }^{5}$ Department of Geography and Geomatics, University of Glasgow, Glasgow G12 8QQ, Scotland \\ ${ }^{6}$ Department of Geography, University of Edinburgh, Drummond Street, Edinburgh EH8 9XP, Scotland
}

\begin{abstract}
Three early-melt-season high-velocity events (or "spring events") occurred on Haut Glacier d'Arolla, Switzerland, during the melt seasons of 1998 and 1999. The events involve enhanced glacier velocity during periods of rapidly increasing bulk discharge in the proglacial stream and high subglacial water pressures. However, differences in spatial patterns of surface velocity, internal ice deformation rates, the spatial extent of high subglacial water pressures and in rates of subglacial sediment deformation suggest different hydrological and mechanical controls. The data from two of the events suggest widespread ice-bed decoupling, particularly along a subglacial drainage axis creating the highest rates of basal motion and "plug flow" in the overlying ice. The other event showed evidence of less extensive ice-bed decoupling and sliding along the drainage axis with more mechanical support for ice overburden transferred to areas adjacent to decoupled areas. We suggest that: (1) plug flow may be a common feature on glaciers experiencing locally induced reductions in basal drag; (2) under certain circumstances, enhanced surface motion may be due in part to non-locally forced enhanced bed deformation; and (3) subglacial sediment deformation is confined to a depth of the order of centimetres to decimetres.
\end{abstract}

\section{INTRODUGTION}

Early-melt-season rainstorms and/or high melt rates lead to rapid increases in surface water inputs to a subglacial drainage system that is poorly developed and has low capacity at that time of year. This input may result in hydraulic and mechanical instabilities (Kavanaugh and Clarke, 2001). Such instabilities typically last a few hours or days and are often called "spring events" (Röthlisberger and Lang, 1987). Spring events seem to be a common feature of valley glaciers. They have been recorded on Unteraar- and Findelengletscher, Switzerland (Iken and others, 1983; Iken and Bindschadler, 1986), and Storglaciären, Sweden (Hooke and others, 1989). At Haut Glacier d'Arolla, Switzerland, an event was monitored in 1994 (22-28 June (D173-179, where $\mathrm{D}$ is day of year)) (Mair and others, 2001) and two were recorded in 1995 (29 June-4 July (D180-185) and 7-16 July (D188-197)) (Mair and others, 2002b). Spring events are associated with a reorganization of subglacial drainage (Stone and Clarke, 1996; Gordon and others, 1998; Kavanaugh and Clarke, 2001; Mair and others, 2002a), and marked increases in glacier surface motion (Iken and others, 1983; Iken and Bindschadler, 1986; Hooke and others, 1989; Mair and others, 2001, 2002b). For these reasons, spring events are usually interpreted in terms of hydraulically induced reduc- tions in basal drag and associated increases in basal motion by sliding and/or sediment deformation.

A force-budget approach has recently been used to identify changes in basal drag beneath the tongue of Haut Glacier d'Arolla during a spring event. Results suggest that spring events on this glacier are due to the creation of areas of unusually low basal drag ("slippery spots") along a subglacial drainage axis and the removal of areas of high basal drag ("sticky spots") in surrounding areas. These changes were assumed to be hydraulically induced because of the close association between spatial patterns of low basal drag and subglacial drainage pathways. Similar conclusions were reached based on the interpretation of the response of 42 down-borehole instruments during a spring event on Trapridge Glacier, Yukon Territory, Canada (Kavanaugh and Clarke, 2001). Here, episodes of fast basal motion resulted from the failure of a sticky spot following its hydraulic connection to a nearby drainage pathway.

Each of these conclusions had important limitations. The measurements of surface motion on Haut Glacier d'Arolla were not accompanied by simultaneous measurements of basal hydraulic and mechanical conditions. Conversely, the high-resolution measurements of basal conditions at Trapridge Glacier were not made together with surface motion measurements. Moreover, neither study monitored 


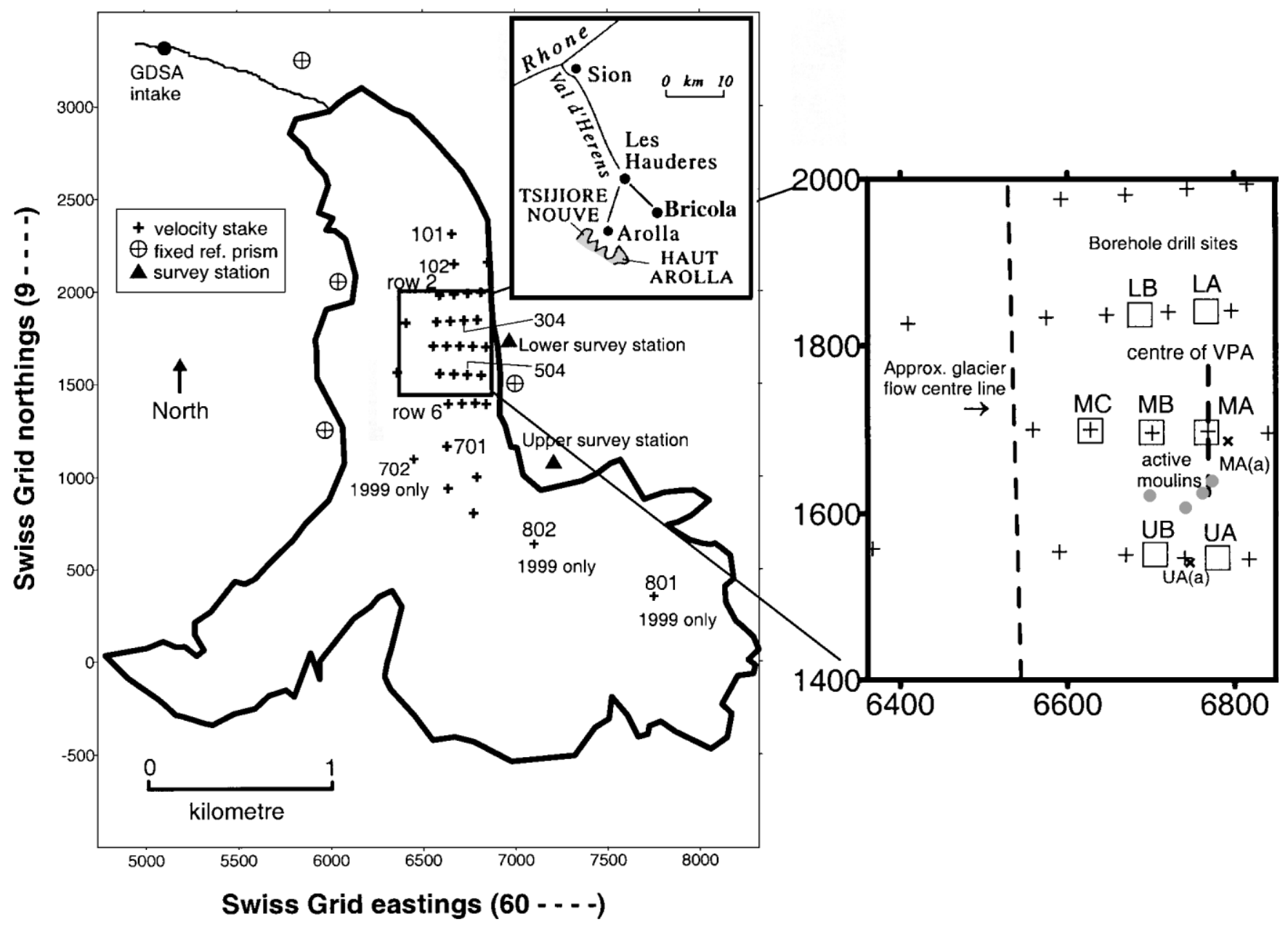

Fig. 1. Haut Glacier d'Arolla field site, 1998-99. Locations of survey stations, fixed reference prisms, surface velocity stakes, borehole drill sites, active moulins, glacier-flow centre line and variable-pressure axis (VPA, defined in text) are shown.

the spatial and temporal changes in internal ice deformation associated with the events. This final limitation may be particularly important, since it is now widely recognized that reduced basal drag and enhanced basal motion in one part of a glacier may, through longitudinal and lateral stress coupling, influence basal motion elsewhere (Hooke and others, 1992; Harbor and others, 1997; Blatter and others, 1998; Hanson and others, 1998; Fischer and Clarke, 2001). Similarly it is apparent that basal motion and internal deformation cannot be considered independently (Harbor and others, 1997). The interdependence of basal motion and internal ice deformation has been demonstrated by the three-dimensional (3-D) ice-flow modelling results of A. Hubbard and others (1998). This model predicted that under prescribed boundary conditions of enhanced sliding along a subglacial drainage axis, basal slip essentially provided the whole component to surface movement, enabling the overlying ice to move as a vertical column over its bed, that is, as "plug flow". Thus, local variations in ice surface velocity can be due to either local variability in basal hydraulic forcing and drag or non-local forcing through stress coupling.

Herein, we aim to contribute to a better understanding of: (1) basal processes during periods of enhanced glacier motion; and (2) the effect of enhanced basal flow regimes on velocity distribution and stress gradients within overlying ice. The results should be useful in calibrating and testing numerical models of valley glacier flow (e.g. A. Hubbard and others, 1998).

\section{FIELD SITE AND METHODS}

Haut Glacier d'Arolla is located at the head of Val d'Hérens, Valais, Switzerland (Fig. 1). The glacier consists of a $2.2 \mathrm{~km}$ long, south-north-trending tongue, approximately 750$800 \mathrm{~m}$ wide, fed by two separate firn basins. The glacier snout lies at 2560 m.a.s.l., while the main eastern basin and the tributary western basin rise to 3500 and $3325 \mathrm{~m}$ a.s.l. respectively. The centre-line length of the main glacier is about $4 \mathrm{~km}$, and the total glacier area is $6.33 \mathrm{~km}^{2}$. Since 1992, an area of the glacier tongue about $1.5 \mathrm{~km}$ from the snout and extending from the eastern margin to the glacier centre line, has been the subject of detailed investigations of englacial hydrology (Copland and others, 1997; Kulessa and Hubbard, 1997; Gordon and others, 1998; B. Hubbard and others, 1998), subglacial hydrology and hydrochemistry (Hubbard and others, 1995; Lamb and others, 1995; Gordon and others, 1998; Nienow and others, 1998), and glacier motion (Harbor and others, 1997; Mair and others, 2001, 2002b). The field measurements described in this paper were also recorded in this area (Fig. 1). Ice thickness here ranges from $130 \mathrm{~m}$ along the centre line to $30 \mathrm{~m}$ nearer the glacier margins, where ice-cored moraines flank the valley sides. Fieldwork was undertaken from mid-May to midAugust 1998 and between late May and late August 1999, and had two main components: ground surveying of an extensive network of surface velocity stakes, and deployment of down-borehole instrumentation to continuously monitor 
a

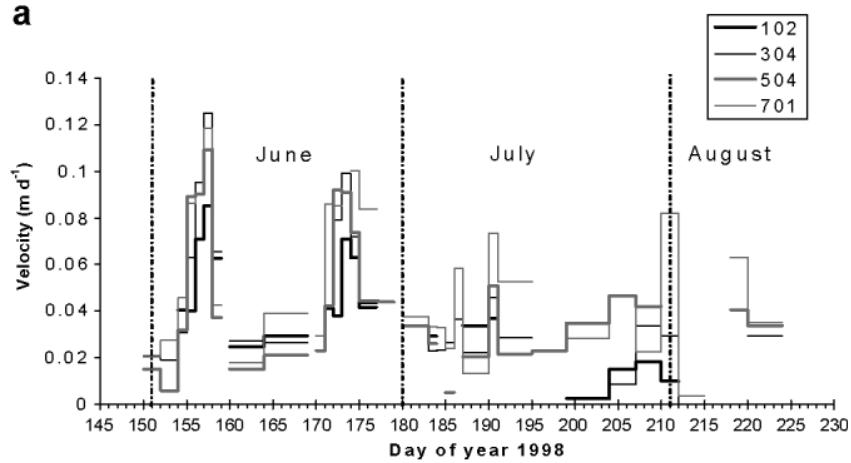

b

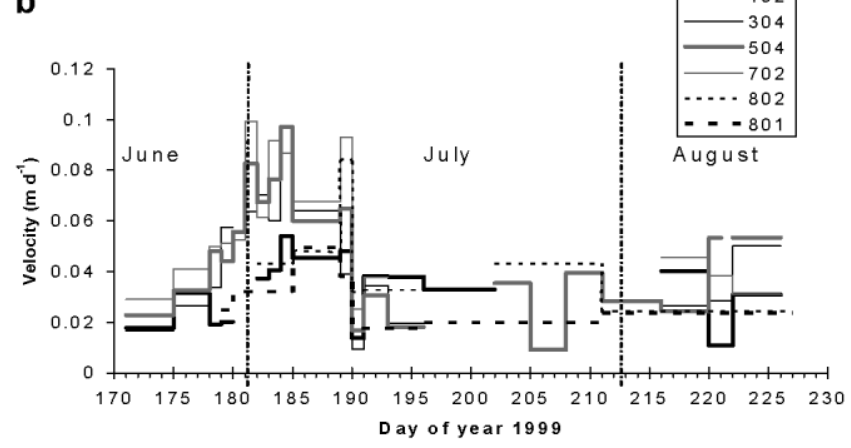

Fig. 2. Surface longitudinal velocities $\left(m d^{-1}\right)$ for selected centre-line stakes: (a) 1998; (b) 1999.

changes in basal and internal processes influencing patterns of glacier flow.

The stake network was centred around seven drill sites where the borehole experiments were conducted (Fig. 1). These seven sites were located with reference to what was already known about the subglacial drainage system in this part of the glacier (Fig. 1). Sites UA, MA and LA were located on a previously identified preferential drainage axis (Sharp and others, 1993) along which, at least in late summer, water flow is channelized, hydraulically efficient and experiences large diurnal water-pressure fluctuations (Hubbard and others, 1995; Gordon and others, 1998). Following Hubbard and others (1995), we hereafter refer to this drainage axis as the variable-pressure axis (VPA; $\mathrm{U}, \mathrm{M}$ and $\mathrm{L}=$ upper, middle and lower; A, B and C increase systematically westward from the VPA). Sites UB, MB and LB were located $\sim 70 \mathrm{~m}$ west of the VPA, where water flow is largely distributed but where, at least in late summer, weak diurnal water-pressure variations occur. These variations lag those along the VPA by $4-5$ hours (Hubbard and others, 1995). Site MC lay a further $70 \mathrm{~m}$ to the west, about $70 \mathrm{~m}$ from the glacier centre line, where water flow is believed to be distributed throughout the year and which previous measurements indicate to be completely hydraulically isolated from the channel on the VPA (Hubbard and others, 1995). The seven sites were instrumented in May 1998 with pressure transducers to measure subglacial water pressure $\left(p_{\mathrm{w}}\right)$, ploughmeters to measure subglacial sediment strength (following Fischer and Clarke, 1994), subglacial tiltmeters to measure bed deformation (following Porter and Murray, 2001), drag-spools to measure sliding (following Blake and others, 1994), and englacial tilt cells at $50 \%$ and $90 \%$ of ice depth to characterize the internal deformation profiles. Detailed descriptions of the deployment, calibration and logging of instrumentation, together with discussion of errors associated with the measurements obtained, are included in the Appendix.

\section{RESULTS}

\section{Temporal and spatial patterns of surface velocities}

Surface horizontal velocities measured throughout the 1998 and 1999 melt seasons are shown for selected centre-line stakes in Figure 2. For most of the time, the glacier tongue flows at fluctuating background speeds of $\sim 0.01-0.05 \mathrm{~m} \mathrm{~d}^{-1}$. The most striking feature of the velocity records is the occurrence, in the early part of the melt season of both years, of events during which velocities rise to $\sim 0.10-0.12 \mathrm{~m} \mathrm{~d}^{-1}$ (representing a two- to ten-fold increase over background speeds). As a result of their consistent timing, we refer to these speed-up events as "spring events". There were two short events in 1998 (4-7 June (D155-158) and 21-26 June (D172-175) and one longer event in 1999 (1-9 July (D182190)).

Poor weather (particularly periods of high rainfall) prohibited a continuous record of surface velocity across the entire study area. Figures 3-5 show surface longitudinal velocities for time intervals during which there is good spatial coverage of data before, during and after the events (N.B. there was good spatial coverage for only the first 4 days of the 1999 event). During the first 1998 event and the 1999 event, the approximate axis of maximum surface velocity is deflected away from the glacier centre line ( easting 606550) towards a more easterly position ( easting 606750) close to the VPA (Figs 3 and 5). This is most distinct in the area close to and down-glacier from a cluster of active moulins. During the second 1998 event, the zone of maximum velocity remained nearer the glacier's centre line (Fig. 4).

\section{Meteorology, stream discharge and borehole- instrumentation data throughout spring events}

All three spring events occurred while the glacier was still snow-covered. They were each associated with rapid rises in proglacial stream discharge $\left(\Delta Q_{\mathrm{w}}=3-4 \mathrm{~m}^{3} \mathrm{~s}^{-1}\right)$ (Figs $6 \mathrm{c}$ and $7 \mathrm{c}$ ) and with substantial increases in proglacial stream turbidity (from $\sim 150 \mathrm{mg} \mathrm{L}^{-1}$ to $>2100 \mathrm{mg} \mathrm{L}^{-1}$ ) (Swift, 2002). The main features of meteorology, stream discharge and borehole-instrumentation datasets during each of the spring events are now summarized. It should be stressed that meteorological data were gathered at a weather station $10 \mathrm{~km}$ from the glacier. Although precipitation can vary greatly over short distances in mountainous areas, field notes describing weather conditions on the glacier are consistent with these temporal weather patterns.

\section{First 1998 spring event ( D155-158)}

The first 1998 event was coincident with heavy rainfall ( $>25 \mathrm{~mm}$ in 24 hours with a maximum rate of $>5 \mathrm{~mm} \mathrm{~h}^{-1}$ ) (Fig. 6a) and high melt (air temperature $>\sim 10^{\circ} \mathrm{C}$ ) (Fig. 6b). Water pressure, $p_{\mathrm{w}}$, at sites MA and LB was low immediately before the event, but during the event it rose from less than local ice overburden $\left(p_{\mathrm{i}}\right)$ to above $p_{\mathrm{i}}$ and then fell (Fig. 8a). Short-lived $p_{\mathrm{w}}$ peaks occurred during individual rainstorms. At sites closer to the glacier centreline (e.g. site $\mathrm{MC}$ ), $p_{\mathrm{w}}$ was high $\left(\geq p_{\mathrm{i}}\right)$ before, during and after the event, and showed only minor fluctuations during the event (bh98-9 in Fig. 8a). During the event, the force on the ploughmeter at site MA 


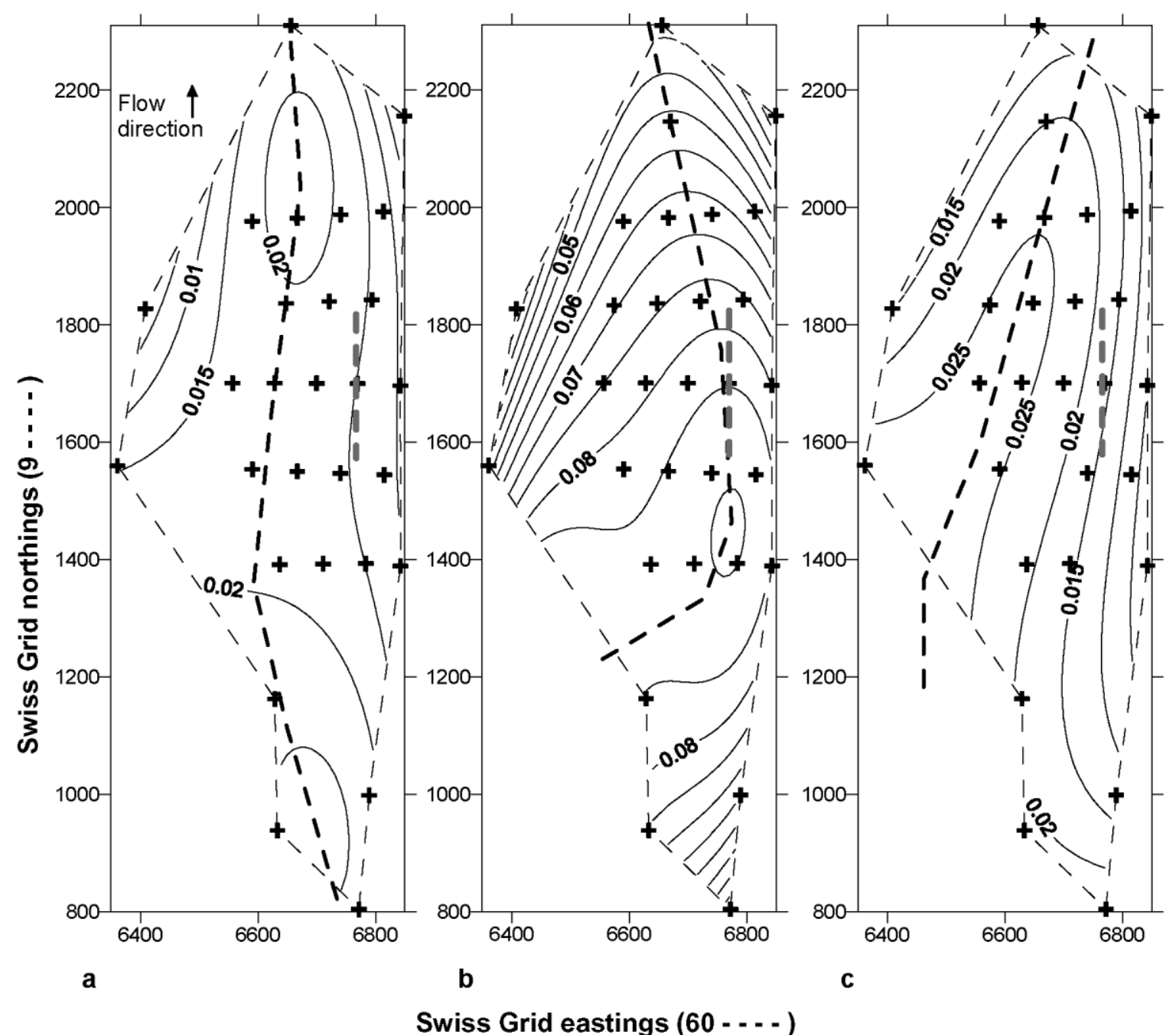

Fig. 3. Spatial pattern of surface longitudinal velocities $\left(m d^{-1}\right)$ before, during and after the first 1998 spring event: (a) before, D150-154; ( b) during, D154-158; and ( c) after, D160-164. Crosses mark location of velocity stakes. Heavy black dashed line marks approximate axis of highest surface velocities. Grey dashed line marks centre of VPA.

was relatively low but with large, short-lived peaks (Fig. 8b). The force rose after the event. Subglacial tilt-cell angles at sites LA (Fig. 8c) and LB (Fig. 8d) remained fairly constant during the event but there were sudden, short-term, large changes in tilt followed by more gradual returns to the average values. These disturbances occurred at the same times as the short-term increases in ploughmeter force at site MA, peaks in $p_{\mathrm{w}}$ at sites $\mathrm{MA}$ and $\mathrm{LB}$, and periods of heavy rainfall. During the event, englacial tilt cells generally showed a greater rate of change of tilt at $90 \%$ compared to $50 \%$ ice depth.

\section{Second 1998 event ( D172-177)}

This event was coincident with a prolonged period of high air temperatures causing high melt (Fig. 6b). Water pressure rose and fell markedly at sites MA and MA(a) only (Fig. $8 \mathrm{a})$. At site $\mathrm{LB}, p_{\mathrm{w}}$ remained well below $p_{\mathrm{i}}$ throughout the event, although a clear but short-lived $p_{\mathrm{w}}$ peak (starting at D177.6 and peaking at D177.8) occurred just after $p_{\mathrm{w}}$ at sites MA and MA(a) fell at the end of the event (Fig. 8a). At site $\mathrm{MC}, p_{\mathrm{w}}$ remained $\geq p_{\mathrm{i}}$ and diurnal fluctuations became more pronounced during the event. Ploughmeter force decreased then increased at site MA, mirroring the $p_{\mathrm{w}}$ rise and fall at this site (Fig. 8b and a). Subglacial tilt-cell angles at sites LA and LB (especially of the top cells) systematically increased during the event (Fig. 8c and d). Subglacial and englacial tilt-cell records show just one big disturbance after the event at D177.6 which affected all drill sites (Fig. 8e).

\section{9 event ( D182-190)}

Most of the 1999 event was coincident with a prolonged period of high air temperatures causing high melt (D182187, Fig. 7b), whilst the final days (D187-189) were coincident with a period of high rainfall (Fig. 7a). By the time of the 1999 event, the only water-pressure transducers still working from the previous summer were at sites MA and $\mathrm{MB}$, but a third transducer had been successfully deployed in a new borehole drilled between sites UA and UB (site $\mathrm{UA}(\mathrm{a})$; Fig. 1). All three records indicate high $p_{\mathrm{w}}$ before the event, with the pressure rising still further during the event (Fig. 9a). The highest increases occurred at sites MA and $\mathrm{UA}(\mathrm{a})$ which were closest to the drainage axis (Fig. 9a). At all three sites, $p_{\mathrm{w}}$ began to fall at the same time towards the end of the event on D187. The fall was more gradual at site MA. Subglacial tilt cells at site MB showed reductions in tilt rates during the time of highest $p_{\mathrm{w}}$ around D182-187 (Fig. $9 b)$. Large disturbances in tilt on JD187 followed by increased tilt rates exactly coincided with the slight fall in $p_{\mathrm{w}}$ at or close to this site.

We can analyze the changes in tilt rate of the englacial tilt cells in order to estimate the changing contribution of 


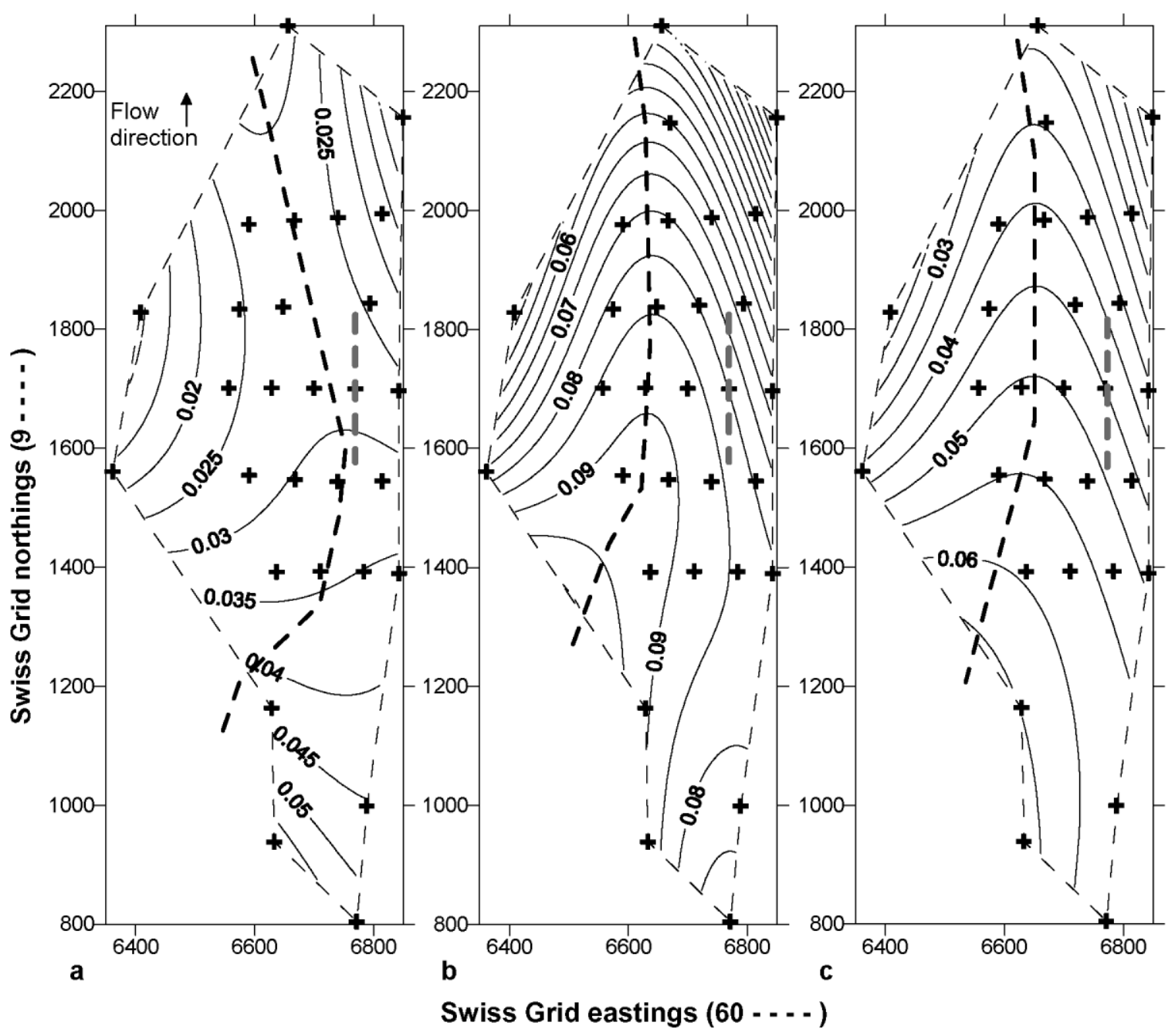

Fig. 4. Spatial pattern of surface longitudinal velocities $\left(m d^{-1}\right)$ before, during and after the second 1998 spring event: (a) before, D170-172; (b) during, D172-175; and (c) after, D175-177. Crosses mark location of velocity stakes. Heavy black dashed line marks approximate axis of highest surface velocities. Grey dashed line marks centre of VPA.

internal ice deformation to surface velocity. Assuming simple shear, the vertical velocity gradient $\partial u / \partial z=$ $\partial \tan \theta_{\mathrm{d}} / \partial t$, where $u$ is longitudinal (down-flow) velocity, $z$ is the vertical component of distance, directed downwards, and $\theta_{\mathrm{d}}$ is the change of longitudinal tilt angle over a time interval $t$. The vertical velocity gradient was calculated at two known depths from changes in englacial tilt over an annual period (August 1998-August 1999) and during the 1999 spring event (D181-185) for selected sites (Table 1). The analysis was carried out at four sites where tilt cells were not affected by disturbances during the event. At all sites, $\partial u / \partial z$ is greater at $90 \%$ than $50 \%$ over the annual period. This is consistent with ice-flow theory that predicts that deformation is concentrated near the glacier bed.

During the 1999 spring event, values of $\partial u / \partial z$ will be expected to differ since they are calculated over a short 4 day "snapshot" compared with the long-term annual average. Despite this expectation, the following features of the data are considered significant when comparing the 1999 spring event with the annual average. At site MA (directly over the subglacial drainage axis), $\partial u / \partial z$ is much less at both $90 \%$ and $50 \%$ ice depth. At site UB there is a similarly large reduction in $\partial u / \partial z$ at $90 \%$. At sites LA and LB there is little change in $\partial u / \partial z$ at $90 \%$, compared with the annual average, but site LA shows a very large increase at 50\%.

\section{INTERPRETATION OF HYDROLOGY AND DYNAMICS DURING SPRING EVENTS}

\section{Subglacial hydrology before the 1998 spring events}

Before the first 1998 spring event, the glacier was snow-covered and bulk discharge was low. Previous dye-tracing and borehole water-level results indicate that at this stage of the melt season this area of the glacier is typically underlain by a hydraulically inefficient distributed drainage system

Table 1 . The rate of change of longitudinal velocity, $u$, with respect to depth, z, at $90 \%$ and $50 \%$ ice depth at selected sites as derived from englacial tilt cells

\section{$\partial u / \partial z$}

Site Annual average (1998-99) 1999 spring event (D181-185) $90 \%$ depth $\quad 50 \%$ depth $\quad 90 \%$ depth $\quad 50 \%$ depth $\mathrm{a}^{-1} \quad \mathrm{a}^{-1} \quad \mathrm{a}^{-1} \quad \mathrm{a}^{-1}$

\begin{tabular}{ccccc}
\hline MA & 0.18 & 0.11 & 0.05 & -0.01 \\
UB & 0.13 & 0.02 & 0.00 & 0.09 \\
LA & 0.22 & 0.05 & 0.18 & 0.23 \\
LB & 0.27 & 0.00 & 0.28 & 0.07 \\
\hline
\end{tabular}




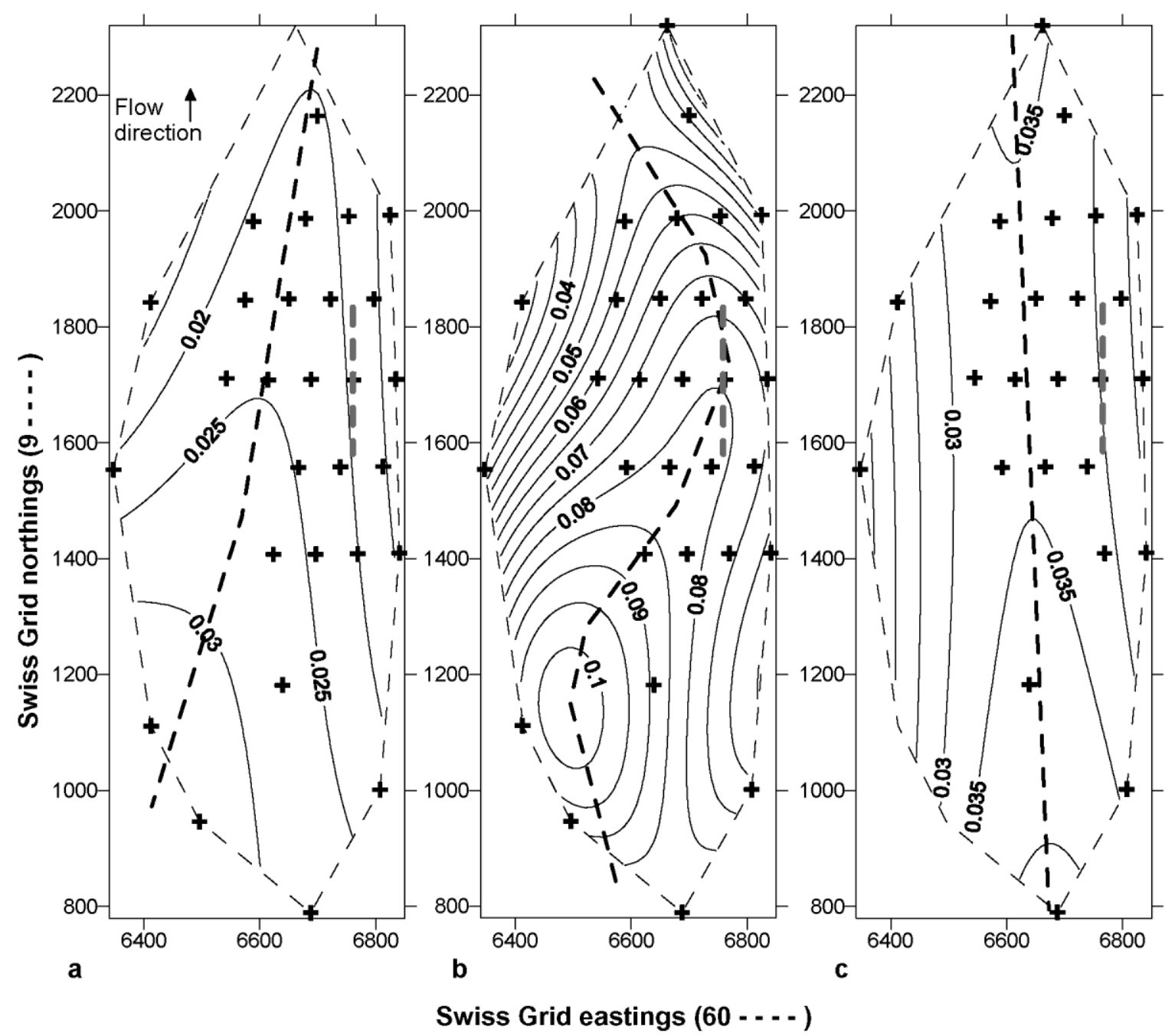

Fig. 5. Spatial pattern of surface longitudinal velocities ( $m d^{-1}$ ) before, during and after the 1999 spring event: $(a)$ before, D171-175; ( $b$ ) during, D181-185; and (c) after, D191-193. Crosses mark location of velocity stakes. Heavy black dashed line marks approximate axis of highest surface velocities. Grey dashed line marks centre of VPA.

(Gordon and others, 1998; Nienow and others, 1998). However, the low water pressure at site MA (on the VPA) and the high water pressure at site MC $(\sim 140 \mathrm{~m}$ west of the centre of the VPA) is consistent with the presence of a much more hydraulically efficient drainage system along the VPA. Indeed the hole at site MC may not have connected to the subglacial drainage system, or it may have connected to a very inefficient, high-pressure distributed drainage system. Moreover, the intermediate water pressures at site MA(a) ( $\sim 20 \mathrm{~m}$ east of the VPA) and site LB ( $\sim 70 \mathrm{~m}$ west of the VPA) suggest that this more efficient subglacial drainage system affects basal water pressure up to $\sim 70 \mathrm{~m}$ from the centre of the VPA. The presence of a hydraulically efficient drainage system in late May, when this part of the glacier is still covered with $\sim 2 \mathrm{~m}$ of snow, implies that low discharges of basal melt have continued to be directed along the VPA throughout the winter, preventing it from closing up completely by ice deformation.

\section{First 1998 spring event}

The first 1998 event began when intense rainstorms, high air temperatures and strong föhn winds caused rapid melting of the snowpack and high input of water to the hydraulically inefficient drainage system. Away from the VPA (site MC), water pressures remained high (equal to or greater than ice overburden) but experienced minor fluctuations. Surface velocity increased across the whole study area. It is probable that rain- and meltwater accessed all areas of the bed and basal motion increased everywhere. The largest and most rapid rises in water pressure occurred along (site MA) and adjacent to (sites MA(a) and LB) the VPA (Fig. 8), and the axis of highest surface velocity moved away from the glacier centre line towards the VPA (Fig. 3). This suggests that basal motion was highest along the drainage axis. These results suggest that high water pressures caused the glacier to be decoupled from the bed across a large area, centred on theVPA.

Force on the ploughmeter at site MA during the event was low, implying relatively low till strength (Fig. 8b). This suggests that the high water pressures may have weakened subglacial till. If basal sediment in the vicinity of site MA behaves as a viscous material, then large, short-lived force maxima on the ploughmeter may have been due to coincident peaks in basal motion, associated with stick-slip, or to collisions with large clasts during more uniform motion. The rise in ploughmeter force after the first 1998 event corresponds with the drop in water pressure at site MA, and could be due to an increase in the till strength as pore-water pressures within the sediment decreased, creating a stiffer substrate. 
a

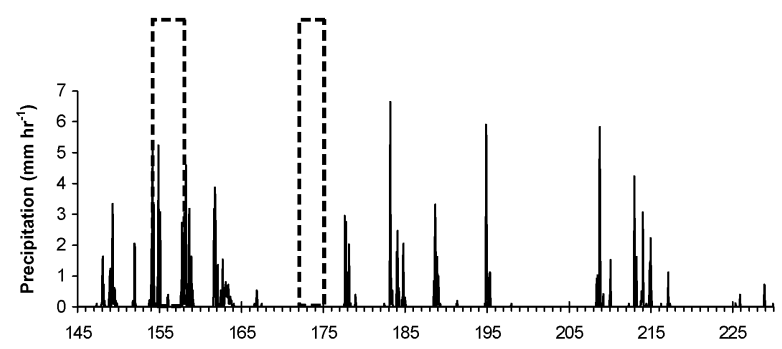

b

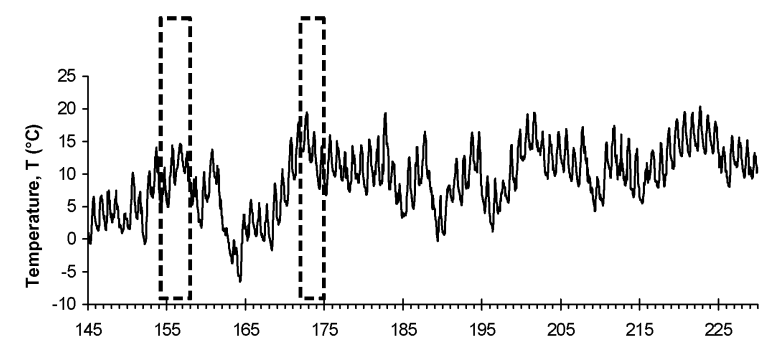

C

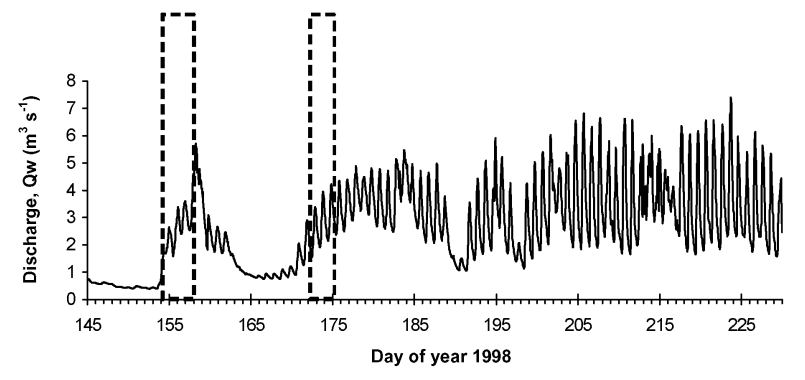

Fig. 6. (a) Bricola weather station precipitation, 1998; (b) Bricola air temperature, T, 1998; and (c) Haut Glacier d'Arolla proglacial stream discharge, Qw, 1998. Dashed lines highlight time periods during spring events (D154-158, cf. Fig. 3b; D172-175, (f. Fig. 4b).

\section{Second 1998 spring event}

The second 1998 event was initiated by rapid melting, and there was no rainfall associated with it. Nearer the centre line ( site MC), water pressures remained high, with slightly stronger diurnal fluctuations. Once again, surface velocity increased across the whole study area, suggesting that basal motion increased everywhere (Fig. 4). Again, big increases in water pressure were recorded at sites MA and at MA(a) (20 m east of the VPA), but this time not at site LB $(\sim 70 \mathrm{~m}$ west of the VPA: Fig. 8a). During this second event, there was no eastward shift in the axis of highest velocities, as occurred during the first event. If basal motion was higher along the drainage axis than elsewhere, then it did not affect a large enough area for this effect to be expressed at the glacier surface. Previous analysis of variations in glacier motion at Findelengletcher (Iken and Truffer, 1997), at Storglaciären (Hanson and others, 1998) and at Haut Glacier d'Arolla (Mair and others, 2001, 2002b) suggest that the spatial extent of regions of high subglacial water pressure/low basal drag is a key component in causing widespread increases in glacier motion. The area of the bed that is affected by high water pressures along the drainage axis will vary depending on the magnitude and the duration of the highwater-pressure event. There appears to be little difference between these characteristics of water pressure at site MA during the first and second 1998 spring events. However, the area of high water pressure will also depend on the hydraulic efficiency of the adjacent drainage system. Down- a

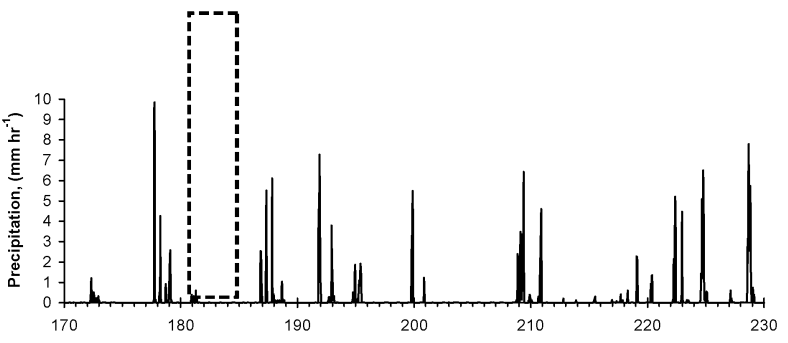

b

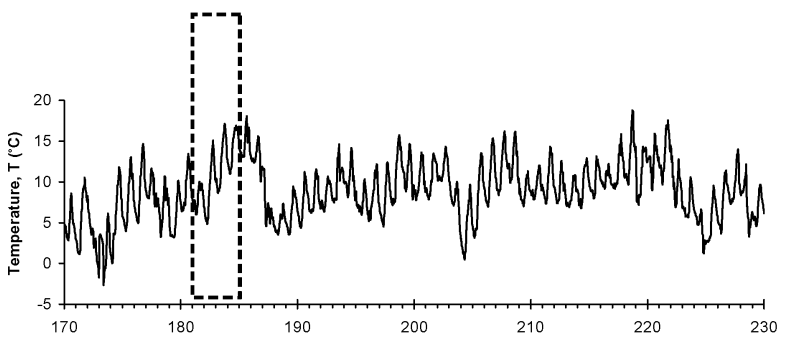

C

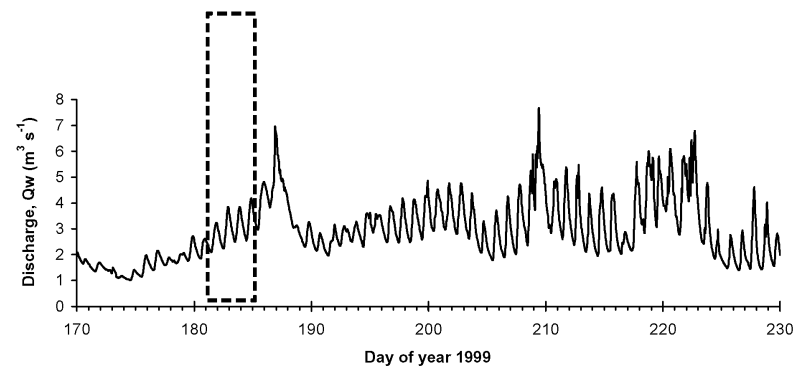

Fig. 7. (a) Bricola weather station precipitation, 1999; (b) Bricola air temperature, T, 1999; and (c) Haut Glacier d'Arolla proglacial stream discharge, Qw, 1999. Dashed lines highlight time period during the spring event (D181-185, cf. Fig. 5b). N.B. spring event continued until D190 (cf. Fig. 2).

glacier from site MA, high water inputs to the system from up-glacier no longer lead to high subglacial water pressures. This suggests an increase in the capacity of the drainage system, which is to be expected as a result of meltwater transfer, conduit enlargement and sediment erosion associated with the first event. These results suggest that during this second event high water pressures caused the glacier to be decoupled across a much smaller area of the bed than during the first event.

The close association between the reduction in force on the ploughmeter and the rise in water pressure at site MA suggests a reduction in sediment strength associated with high pore-water pressure. Sediment strength decreases when water pressure exceeds ice overburden pressure (Fig. $8 \mathrm{a}$ and $\mathrm{b}$ ). The systematic change in bed tilt at sites LA and LB suggests that bed deformation increased at these sites during this event (Fig. 8c and d). At the end of the second event, at D177.6, englacial tilt-cell disturbances at sites MC, LA and LB coincide with disturbance to the subglacial tilt cells at sites LA and LB, and with a sharp rise in water pressure at site LB. These data suggest a short-lived, and possibly quite localized, decoupling event at the ice/bed interface.

\section{9 spring event}

The 1999 event appears to be dynamically more similar to the first 1998 event, but, like the second 1998 event, was initiated and maintained by high melt during warm, windy conditions. High water levels before the event at sites MA, 
a Water pressure
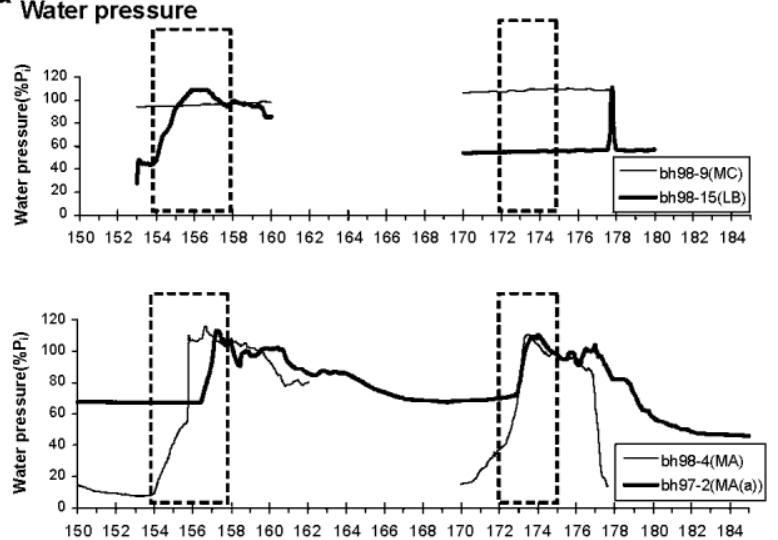

b

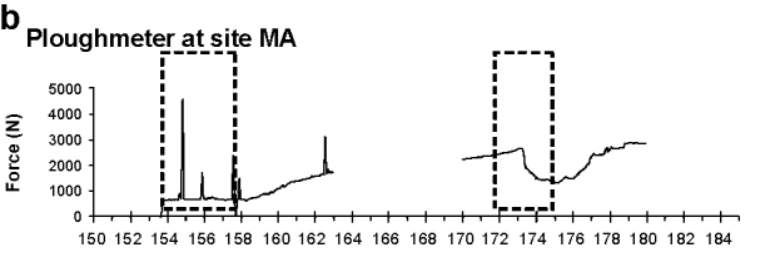

C Bed tilt site LA

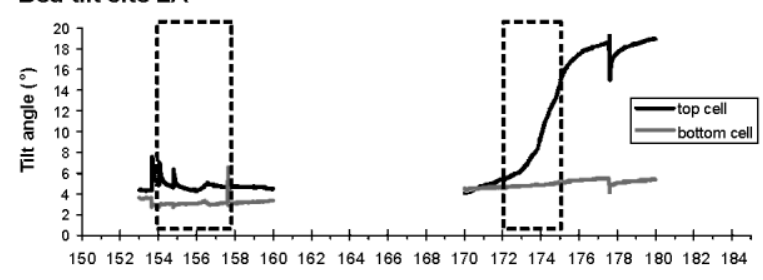

d

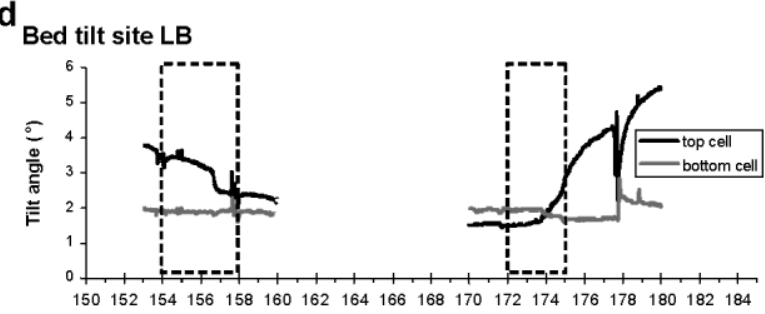

englacial tilt

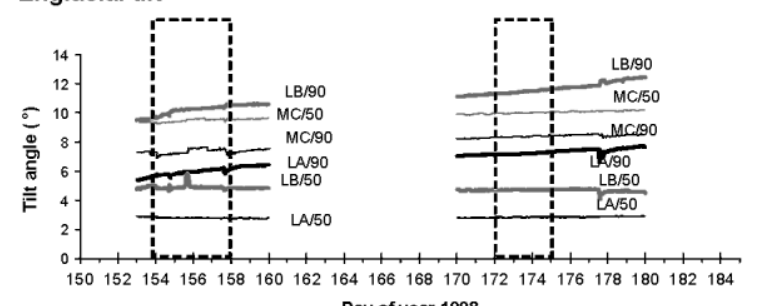

Day of year 1998

Fig. 8. Borehole-instrumentation data, 1998. Dashed lines highlight time periods during spring events (D154-158, cf. Fig. 3b; D172-175, cf. Fig. 4b). (a) Selected borehole water pressures. BH97-2 was deployed during summer 1997 and was located about $30 \mathrm{~m}$ east of site $M A$ at site $M A(a)$ (Fig. 1). Water pressures expressed as a percentage of local ice overburden pressure $\left(P_{\mathrm{i}}\right)$. (b) Data from ploughmeter inserted at site MA. Force record indicates load applied to the tip of the ploughmeter. (c) Tilt angle (from vertical) of bed-tilt cells at site LA. Bottom cell inserted $10 \pm 3 \mathrm{~cm}$ into sediment, with top cell $6.5 \mathrm{~cm}$ above. (d) Tilt angle (from vertical) of bed-tilt cells at site LB. Bottom cell inserted $14 \pm 3 \mathrm{~cm}$ into sediment, with top cell $6.5 \mathrm{~cm}$ above. (e) Tilt angle (from vertical) of selected englacial tiltmeters: LB/90 refers to tilt cell at $90 \%$ ice depth at site LB, etc.
MB and UA(a) suggest that the VPA was dominated by a highly pressurized, hydraulically inefficient drainage system (Fig. 9a). The synchronous increase in surface velocity and basal water pressures suggests a ubiquitous increase in basal motion across the study area. At site MA, very low vertical velocity gradients at depth (Table 1) suggest that internal deformation did not contribute to the big increase in surface velocity. These results suggest that basal motion may have been highest along the VPA, causing "plug flow" in the overlying ice. This appears to be a key area of hydrologically induced basal forcing, probably because of its location with respect to the active moulins mentioned earlier. Plug-flow behaviour would be consistent with the 3-D modelling results of A. Hubbard and others (1998), mentioned earlier, which were characterized by decreased internal deformation rates in areas of high basal sliding. At sites down-glacier of this plug flow, significantly increased vertical velocity gradients at 50\% ice depth (Table 1) may suggest that internal deformation increased during the event, especially at site LA. Here, internal ice deformation may have accounted for some of the increased surface velocity. The data indicate that basal motion is likely to have been less at site LA than further up-glacier at site MA. Increased internal deformation may be associated with high transverse and longitudinal stress gradients within the ice created by this spatial variation in basal motion.

\section{Comparison of the spring events}

The three spring events are superficially similar, in that all involve enhanced glacier velocity during periods of rapidly increasing water discharge. However, different spatial patterns of surface velocity are associated with different hydrological and mechanical controls producing different areas of maximum acceleration. The first 1998 event and the 1999 event were dynamically similar, but one was initiated by precipitation and the other by melt. Conversely, the second 1998 event and the 1999 event were both melt-induced but were dynamically different. These comparisons would suggest that antecedent conditions of the subglacial drainage system may have been more important in creating different hydrological controls on spatial patterns of enhanced motion than differences in the intensity or spatial distribution of surface water inputs. Hydrological and mechanical adjustments during the first 1998 event meant that further down-glacier the subglacial drainage axis was more hydraulically efficient by the time of the second event so that it could accommodate the increased water input. High subglacial water pressures were consequently confined to a smaller area of bed.

\section{Further discussion of patterns of bed deformation}

Two different patterns of behaviour can be detected from records of water pressure and bed deformation during the spring events.

\section{(i) High water pressure - high glacier velocity - negative (or reduced) bed tilt}

After the end of the second 1998 event, water pressure at site LB reached a short-lived peak of $110 \%$ of $p_{\mathrm{i}}$ at JD177.8 which coincided with a sudden decrease in bed tilt (cf. Fig. 8a and d). At site MB during the 1999 event, a slight increase in the already high water pressure was associated with a period of little or no change in bed tilt (cf. D182-187, Fig. 9a and b). 
Zero or negative tilt rates have been measured elsewhere (Blake and others, 1992; Iverson and others, 1995; Hooke and others, 1997; Tulaczyk and others, 2000; Porter and Murray, 2001) and a number of possible explanations have been proposed (summarized by Fischer and Clarke, 2001). However, the apparent association between periods of zero or negative bed tilt, high water pressure and high surface motion has previously been observed only by Iverson and others (1995) at Storglaciären. Iverson and others (1995) suggested that during periods of high water pressure, when the coupling between the ice and the underlying till is reduced, ice-bed separation is increased and subglacial sediment is squeezed into the zone of uplift. This would thicken the basal till and cause the tilt cells, previously inclined in a down-flow direction, to rotate up-glacier towards the vertical. A more recent alternative explanation for negative bed tilt is that glacier uplift causes elastic relaxation in the underlying till as the glacier decouples, leading to an upglacier shearing motion of the sediment (Fischer and Clarke, 1997; Iverson and others, 1999).

(ii) Low water pressure — high glacier velocity — enhanced bed tilt Distinct increases in bed deformation at sites LA and LB during and following the second 1998 spring event (Fig. 8c and d) coincide with relatively low $\left(<60 \% p_{\mathrm{i}}\right)$ and constant $p_{\mathrm{w}}$ at site LB (Fig. 8a). During this event, it is likely that there is a transfer of mechanical support for ice shear stresses from high-water-pressure areas with reduced icebed coupling (such as site MA) to adjacent areas characterized by lower water pressures and increased ice-bed coupling (Murray and Clarke, 1995; Fischer and Clarke, 2001). In addition, this region would have experienced increased basal shear stress due to longitudinal coupling with fastermoving ice located $140 \mathrm{~m}$ further up-glacier at site MA. Enhanced rates of subglacial deformation at sites LA and LB are therefore interpreted as being a consequence of high basal shear stress concentrated within sediments strongly coupled to the glacier sole. Bed deformation appears to be confined to a depth of $<\sim 8 \mathrm{~cm}$, as the increase in tilt is confined to the upper tilt cells, leaving the lower tilt cells relatively unaffected. This is consistent with previous observations at Hagafellsjökull Vestari, Iceland, in which pervasive deformation was confined to an upper $(<16 \mathrm{~cm})$ horizon (Fuller and Murray, 2000). Our results are different from those from Breiðamerkurjökull and Skallafellsjökull, Iceland, and Black Rapids Glacier, Alaska, U.S.A., where ductile deformation extended to $>1 \mathrm{~m}$ depth (Boulton and Hindmarsh, 1987; Truffer and others, 2000).

\section{SUMMARY AND GONGLUDING REMARKS}

Earlier investigations of short-term variations in glacier motion at Haut Glacier d'Arolla (Mair and others, 2001, $2002 \mathrm{~b}$ ) were limited by the fact that there were no simultaneous measurements of borehole water pressures, basal motion or the internal velocity distribution. In this study therefore, we attempted to measure, simultaneously, patterns of surface motion, internal deformation, basal motion, substrate properties and subglacial hydrology at a high temporal and spatial resolution during three periods of rapid glacier motion. The data gathered were examined to evaluate how temporal and spatial changes in the subglacial hydrology and substrate properties influence temporal and spatial variations in glacier motion. Results suggest that

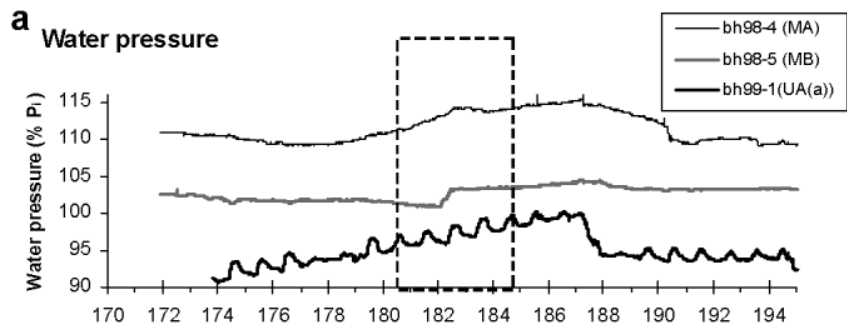

b

Bed tilt at site MB

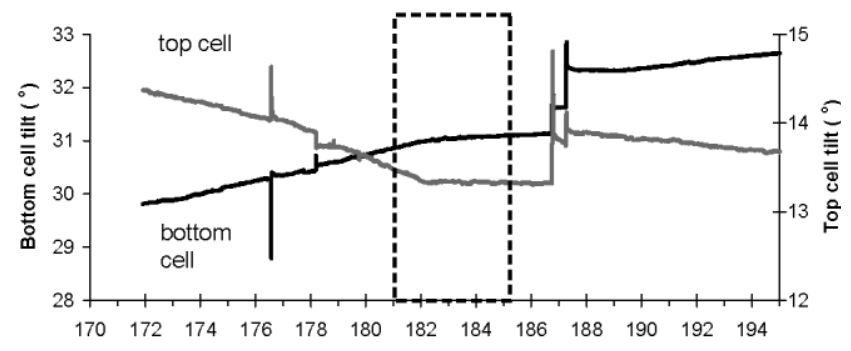

C Englacial tilt

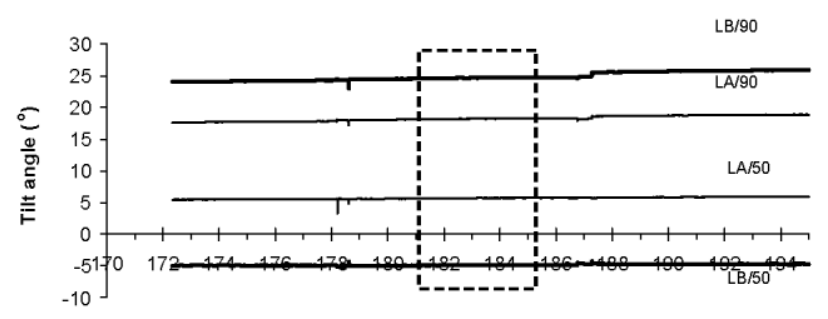

d Englacial tilt

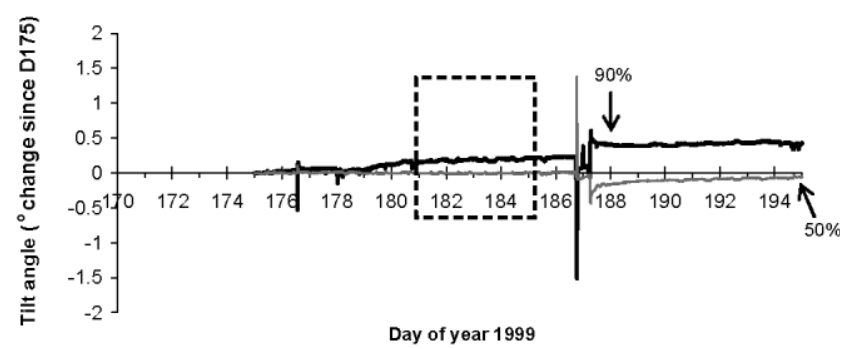

Fig. 9. Borehole instrumentation data, 1999. Dashed lines highlight time period during the spring event (D181-185, cf. Fig. 5b). N.B. spring event continued until D190 (cf. Fig. 2). (a) Borehole water pressures expressed as a percentage of local ice overburden pressure $\left(P_{\mathrm{i}}\right)$. (b) Tilt angle (from vertical) of bed-tilt cells at site MB. Bottom cell inserted $4 \pm 3 \mathrm{~cm}$ into sediment, with top cell $6.5 \mathrm{~cm}$ above. (c) Tilt angle (from vertical) of englacial tiltmeters at sites $L A$ and LB. (d) Change in tilt angle of englacial tilt cells at site $M A$.

two distinct patterns of glacier flow occurred during the spring events.

Pattern 1. The first 1998 spring event and the 1999 event were similarly characterized by:

rapid increase in bulk discharge from the glacier: one initiated by intense rainstorms (first 1998 event), the other by high melt rates (1999 event);

widespread high water pressures, with greatest increases in water pressure along a broad preferential drainage axis that lies east of the glacier centre line; 
enhanced surface motion everywhere and the movement of the axis of highest surface velocities from the glacier centre line towards the drainage axis, probably because the highest rates of basal motion were focused around the drainage axis;

a reduction in bed deformation, suggesting basal motion was accomplished by sliding in response to glacier-bed decoupling;

simultaneous occurrence of disturbances of basal sediments and englacial tilt cells which suggests that the mechanical adjustment of the glacier during the events may have involved stick-slip sliding.

Pattern 2. The second 1998 spring event was characterized by:

increased bulk discharge from the glacier, initiated by high surface melt;

high subglacial water pressures, with greatest increases in water pressure confined to a smaller area of the drainage axis;

enhanced surface motion everywhere, but with the axis of highest surface velocities remaining on the glacier centre line, suggesting that basal motion was not highest along the drainage axis;

increased rates of bed deformation in the upper layers of subglacial sediment, where ice was coupled to the bed and where longitudinal and/or transverse stress gradients caused high basal shear stress.

Events which involve widespread high-water-pressure forcing along preferential drainage axes (pattern 1) involve widespread ice-bed decoupling and sliding. Spatial variations in sliding rate produce high longitudinal and transverse stress fields and complex mechanical adjustment that may involve stick-slip motion at the bed. The net result is a marked change in the spatial pattern of surface velocity compared with the long-term average. Events which involve a more localized high-water-pressure forcing (pattern 2) cause more localized ice-bed decoupling and sliding. Mechanical support for ice shear stress is transferred to areas adjacent to decoupled areas, causing enhanced, nonlocally forced basal motion in these regions. This results in a more even distribution of basal motion and little change in the spatial surface pattern of surface velocity. Antecedent conditions of the subglacial drainage system may have been more important in creating different hydrological controls on each pattern of enhanced motion than differences in the intensity of surface water inputs associated with rainstorms or surface melt.

We have evidence to support the idea that plug flow may be a common feature on glaciers experiencing locally induced reductions in basal drag over areas of the order of one ice thickness and greater (Hooke and others, 1992; Harbor and others, 1997; A. Hubbard and others, 1998). Our findings also indicate that, under certain circumstances, enhanced surface motion may be due in part to non-locally forced enhanced bed deformation. Finally, results of this study are consistent with the findings of Fuller and Murray (2000), that subglacial sediment deformation is confined to a depth of the order of centimetres to decimetres, and are different from the findings of Boulton and Hindmarsh (1987) and Truffer and others (2000) who found that pervasive deformation can occur throughout the sediment thickness.
Similar spatial and temporal patterns in the relative importance of ice deformation and basal motion to glacier surface motion, as discussed during spring events in this paper, have also been observed at seasonal time-scales in another paper (Willis and others, 2003).

\section{ACKNOWLEDGEMENTS}

Our work was supported by U.K. Natural Environment Research Council grant GR3/11216. The paper was written whilst D.M. was in receipt of postdoctoral funding from the Leverhulme Trust. We thank M. Sharp and H. Blatter for stimulating discussion of ideas leading to this research. P. Porter provided helpful advice about the design, calibration and deployment of tiltmeters. We thank J. Luthiger and A. Hayes for assistance with the design and construction of other down-borehole instruments. Fieldwork was carried out with much help from D. A. Swift, T. Schuler, G. Leysinger Vieli and many others associated with the Arolla Glaciology Project. We thank Grande Dixence SA, Y. Bams, V. Anzevui and P. and B. Bournissen for their logistical support. This paper was improved substantially following the comments of R. LeB. Hooke, S. M. Tulaczyk and the Scientific Editor, K. M. Cuffey.

\section{REFERENGES}

Blake, E.W., Clarke, G.K.C. and Gérin, M.C. 1992. Tools for examining subglacial bed deformation, f.Glaciol., 38(130), 388-396.

Blake, E.W., Fischer, U. H. and Clarke, G. K. C. 1994. Direct measurement of sliding at the glacier bed, F.Glaciol., 40(136), 595-599.

Blatter, H. 1995. Velocity and stress fields in grounded glaciers: a simple algorithm for including deviatoric stress gradients. F.Glaciol., 41 (138), 333-344.

Blatter, H., Clarke, G. K. C. and Colinge, J. 1998. Stress and velocity fields in glaciers: Part II. Sliding and basal stress distribution. F.Glaciol., 44(148), 457-466.

Boulton, G. S. and Hindmarsh, R. G. A. 1987. Sediment deformation beneath glaciers: rheology and geological consequences, f. Geophys. Res., 92(B9), 9059-9082.

Copland L., Harbor, J., and Sharp, M. 1997. Borehole video observation of englacial and basal ice conditions in a temperate valley glacier, Ann. Glaciol., 24, 277-282.

Fischer, U. H. and Clarke, G. K. C. 1994. Ploughing of subglacial sediment, f.Glaciol., 40(134), 97-106.

Fischer, U. H. and Clarke, G. K. C. 1997. Stick-slip sliding behaviour at the base of a glacier, Annals of Glaciology, 24, 390-396.

Fischer, U. H. and Clarke, G. K. G. 2001. Review of subglacial hydro-mechanical coupling: Trapridge Glacier, Yukon Territory, Canada, Quaternary International, 86 (2001), 29-43.

Fuller, S. J. and Murray, T. (2000) Evidence against pervasive bed deformation during a surge of an Icelandic glacier, Special Publication of the Geological Society of London, 176, 203-216.

Gordon, S., Sharp, M., Hubbard, B., Smart, C., Ketterling, B. and Willis, I. 1998 Seasonal reorganization of subglacial drainage system of Haut Glacier d'Arolla, Valais, Switzerland, inferred from measurements in boreholes, Hydrol. Process., 12, 105-133.

Gudmundsson, G. H., A. Bauder, M. Lüthi, U. H. Fischer and M. Funk. 1999. Estimating rates of basal motion and internal ice deformation from continuous tilt measurements. Ann. Glaciol., 28, 247-252

Hanson, B., Hooke, R. LeB. and Grace, E. M. Jr. 1998 Short-term velocity and water-pressure variations down-glacier from a riegel, Storglaciären, Sweden, f.Glaciol., 44(147), 359-367.

Harbor, J. M., Sharp, M., Copland, L., Hubbard, B., Nienow, P. and Mair, D. 1997. The influence of subglacial drainage conditions on the velocity distribution within a glacier cross-section, Geology, 25, 739-742.

Hooke, R. LeB., Calla, P., Holmund, P., Nilsson, M. and Stroeven, A. 1989. A 3 year record of seasonal variations in surface velocity, Storglaciären, Sweden, f. Glaciol., 35(120), 235-247

Hooke, R. LeB., Pohjola, V.A., Jansson, P. and Kohler, J. 1992. Intra-seasonal changes in deformation profiles revealed by borehole studies, Storglaciären, Sweden. f. Glaciol., 38(130), 348-358.

Hooke, R. LeB., Hanson, B., Iverson, N.R., Jansson, P. and Fischer, U.H. 
1997. Rheology of till beneath Storglaciären, Sweden, f. Glaciol., 43(143), 172-179.

Hubbard, A., Blatter, H., Nienow, P., Mair, D. and Hubbard, B. 1998 Comparison of the first order approximation for glacier flow with field data: a study of Haut Glacier d'Arolla, Switzerland, 7. Glaciol., 44(147), 368378.

Hubbard, B., Sharp, M., Willis, I., Nielsen, M. and Smart, C. 1995. Borehole water-level variations and the structure of the subglacial drainage system of Haut Glacier d'Arolla, Valais, Switzerland, f. Glaciol., 41 (139), 572583.

Hubbard, B., Binley, A., Slater, L., Middleton, R. and Kulessa, B. 1998. Inter-borehole electrical resistivity imaging of englacial drainage, f. Glaciol., 44(137), 429-434.

Iken, A. and Bindschadler, R. A. 1986. Combined measurements of subglacial water pressure and surface velocity of the Findelengletscher, Switzerland: conclusions about drainage system and sliding mechanism, $\mathcal{F}$. Glaciol., 32(110), 101-119.

Iken, A. and Truffer, M. 1997. The relationship between subglacial water pressure and velocity of Findelengletscher, Switzerland, during its advance and retreat, f.Glaciol, 43(144), 328-338.

Iken, A., Röthlisberger, H., Flotron, A. and Haeberli, W. 1983. The uplift of Unteraargletscher at the beginning of the melt season - a consequence of water storage at the bed?, f. Glaciol., 29(101), 28-47.

Iverson, N. R., Hanson, B., Hooke, R. LeB. and Jansson, P. 1995. Flow mechanism of glaciers on soft beds, Science, 267, 80-81.

Iverson, N. R., Baker, R.W., Hooke, R. LeB., Hanson, B. and Jansson, P. 1999. Coupling between a glacier and a soft bed, f. Glaciol., 45(149), 3140.

Kavanaugh, J. L. and Clarke, G.K.C. 2001. Abrupt glacier motion and reorganization of basal shear stress following the establishment of a connected drainage system, f.Glaciol., 47(158), 472-480.

Kulessa, B. and Hubbard, B. 1997. Interpretation of borehole impulse tests at Haut Glacier d'Arolla, Switzerland, Ann. Glaciol., 24, 397-402.

Lamb, H. R. and 7 others (1995), The composition of subglacial meltwaters sampled from boreholes at the Haut Glacier d'Arolla, IAHS Publication, 228, 395-403.

Mair, D., Nienow, P., Willis, I. and Sharp, M. 2001. Spatial Patterns of Glacier Motion During a High Velocity Event: Haut Glacier d'Arolla, Switzerland, f. Glaciol., 47(156), 9-20.

Mair, D., Sharp, M. and Willis, I. 2002a. Evidence for basal cavity opening from analysis of surface uplift during a high-velocity event: Haut Glacier d'Arolla, Switzerland, fournal of Glaciology, 48(161), 208-216.

Mair, D., Nienow, P., Sharp, M., Wohlleben, T. and Willis, I. 2002b. Influence of subglacial drainage system evolution on glacier surface motion: Haut Glacier d'Arolla, Switzerland, 7. Geophys. Res., 107(B8). (10.1029/ 2001JB000514.

Murray, T. and Clarke, G. K. C. 1995. Black-box modelling of the subglacial water system, 7. Geophys. Res., 100(B7), 10,231-10,245.

Nienow, P., Sharp, M. and Willis, I. 1998 Seasonal changes in the morphology of the subglacial drainage system, Haut Glacier d'Arolla, Switzerland, Earth Surf. Process. Land-forms, 23, 825-843.

Porter, P. and Murray, T. 2001. Mechanical and hydraulic properties of till beneath Bakaninbreen, Svalbard, f. Glaciol, 47(157), 167-175.

Röthlisberger, H. and Lang, H. 1987. Glacial hydrology. In Gurnell, A.M. and Clarke, M.J., editors, Glacio-fluvial sediment transfer: an Alpine perspective. London: Wiley. 207-284.

Sharp, M., Richards K., Willis, I., Arnold, N., Nienow, P., Lawson, W. and Tison, J.-L. 1993. Geometry, bed topography and drainage system structure of the Haut Glacier d'Arolla, Switzerland, Earth Surf. Process. Landforms, 18, 557-571.

Stone, D. B. and Clarke, G. K. C. 1996 In situ measurements of basal water quality and pressure as an indicator of the character of subglacial drainage systems, Hydrol. Processes, 10(4), 615-628.

Swift, D. A. 2002. Provenance of suspended sediment in subglacial drainage systemsi. (Ph.D. thesis, University of Glasgow.)

Truffer, M., Harrison, W. D. and Echelmeyer, K. A. 2000. Glacier motion dominated by processes deep in underlying till, f. Glaciol, 46(153), 213221.

Tulaczyk, S. M., Kamb, B. and Engelhardt, H.F. 2000. Basal mechanics of Ice Stream B, West Antarctica. I. Till mechanics, f. Geophys. Res., 105(B1), 463-481.

Willis, I., Mair, D., Hubbard, B., Fischer, U.F., Nienow, P., Hubbard, A. 2003. Seasonal variations in ice deformation and basal motion, Haut Glacier d'Arolla, Switzerland, Annals of Glaciol. 36, 157-167.

\section{APPENDIX}

\section{METHODS OF FIELD DATA GOLLEGTION}

\section{Surface velocity surveys}

The positions of 30 prisms fixed to stakes drilled into the glacier were surveyed every $1-5$ days from a moraine on the eastern valley side (Fig. 1). Due to landslide danger, it was not possible to use bedrock survey stations that had been used in previous years (e.g. Mair and others, 2001). As the moraine was not stationary, its position was fixed at the time of each survey using up to 15 surveys made to three (1998) or four (1999) fixed bedrock markers/prisms in the proglacial area and on the eastern and western valley sides (Fig. 1). Surveys were made using a Geodimeter 410 total station. The rated accuracy of the total station, the refraction error of the prisms and human error in repeat surveying meant that stake positions could be determined with an accuracy of $\pm 5-8 \mathrm{~mm}$ over the range of distances surveyed. The resulting survey data were used to calculate surface velocity patterns across part of the glacier tongue throughout the spring and summer of 1998 and 1999.

\section{Borehole-instrumentation deployment}

In May and June 1998, 22 boreholes were drilled to the bed (total length drilled $=2462 \mathrm{~m}$ ) at seven sites on the glacier tongue (Fig. 1). Each borehole was inclinometered after drilling to check that the holes were nearly vertical. The base of each borehole was penetrometered after drilling to estimate the minimum thickness of subglacial sediment. Instruments were deployed within three or four separate boreholes, located within 2-3 $\mathrm{m}$ of each other, at each site (Table 2). Seven data loggers recorded all the instrument measurements: three were located at the centre of the middle row of drill sites (i.e. at site $\mathrm{MB}$ ), and two each located at the centre of the upper and lower rows (between sites UA and UB and between sites LA and LB respectively). Measurements were made every $1 \mathrm{~min}$ and averages over the previous ten measurements were recorded by data loggers every $10 \mathrm{~min}$. Instrumentation was successfully deployed at all sites, although a subglacial tiltmeter and a drag-spool could not be installed at site MA due to lack of sediment. Further details of borehole-instrument deployment are contained in Table 2.

Additional boreholes were drilled in August 1998 and then again in June 1999 to replace damaged instruments. In August 1998, additional englacial tilt cells were installed at $75 \%$ and $100 \%$ of ice depth at sites MA and MB to attempt to characterize the internal deformation profiles better. Most of the instruments recorded meaningful data for at least some of the time. The main exceptions were the drag-spools, which failed to yield any sensible data, and the ploughmeters, only one of which recorded any systematic variation in force. In addition, problems with data storage during summer 1998 led to gaps in some of the sensor records. Two pressure transducers installed at the base of boreholes drilled $\sim 30$ m east of site MA (site MA(a), Fig. 1) in 1997 were still working and were logged in the same way as the other transducers during the 1998 and 1999 melt seasons.

\section{Instrumentation description}

Englacial tiltmeters

Each englacial tiltmeter consists of a single dual-axis tilt cell 
Table 2. Borehole sensor deployment, May-June 1998

\begin{tabular}{|c|c|c|c|c|c|c|c|c|c|c|c|c|}
\hline Site & Borehole $\mathcal{N}_{0 .}$. & Northing & Easting & $\begin{array}{c}\text { Depth } \\
\text { m }\end{array}$ & $\begin{array}{l}\text { Date in- } \\
\text { strum:d }\end{array}$ & $\begin{array}{l}\text { Penetr. } \\
\mathrm{cm}\end{array}$ & Inclin. date & $\begin{array}{c}\text { Drag } \\
\text { cm insert. }\end{array}$ & $\begin{array}{c}\text { Bed tilt } \\
\text { cm insert. }\end{array}$ & $\begin{array}{l}\text { Plough } \\
\text { cm insert. }\end{array}$ & $p_{\mathrm{w}}$ & $\begin{array}{c}\text { Englac. tilt } \\
\%\end{array}$ \\
\hline \multirow[t]{4}{*}{ MA } & 1 & 91699 & 606769 & 97 & 18 May & 8 & 18 May & & & & & $50 ; 90$ \\
\hline & 2 & 91701 & 606769 & 115 & & & & & & & & \\
\hline & 3 & 91700 & 606770 & 105 & 17 May & 14 & 18+19 May & & & 13 & & \\
\hline & 4 & 91697 & 606769 & 92 & 19 May & - & 19 May & & & & $*$ & \\
\hline \multirow[t]{3}{*}{ MB } & 5 & 91699 & 606699 & 122 & 21 May & 9 & 19 May & & & 21 & $*$ & \\
\hline & 6 & 91698 & 606700 & 120.5 & 21 May & 9 & 20 May & & 9 & & & $50 ; 90$ \\
\hline & 7 & 91697 & 606699 & 119.5 & 21 May & 9 & 21 May & 11 & & & & \\
\hline \multirow[t]{3}{*}{$\mathrm{MC}$} & 8 & 91700 & 606628 & 129 & 22 May & 6 & 22 May & 9 & & & & \\
\hline & 9 & 91700 & 606630 & 127 & 23+24 May & - & 23 May & & & & $*$ & $50 ; 90$ \\
\hline & 10 & 91701 & 606629 & 130.5 & $25 \mathrm{May}$ & 10 & $23 \mathrm{May}$ & & & 9 & & \\
\hline \multirow[t]{3}{*}{ LA } & 11 & 91843 & 606764 & 98 & 27 May & 20 & 27 May & 10 & & & & \\
\hline & 12 & 91843 & 606766 & 90 & 27 May & 10 & 27 May & & & 12 & & \\
\hline & 13 & 91843 & 606764 & 90.5 & 27 May & 28 & 27 May & & 15 & & $*$ & $50 ; 90$ \\
\hline \multirow[t]{3}{*}{ LB } & 14 & 91837 & 606683 & 113 & 30 May & 12 & 27 May & 8 & & & & \\
\hline & 15 & 91839 & 606684 & 117 & 30 May & 26 & 27 May & & 19 & & $*$ & $50 ; 90$ \\
\hline & 16 & 91839 & 606686 & 113 & 30 May & 9 & 27 May & & & 19 & & \\
\hline \multirow[t]{3}{*}{ UA } & 17 & 91546 & 606776 & 96 & 3 Jun & 6 & 1 Jun & & & 2 & & $50 ; 90$ \\
\hline & 18 & 91547 & 606776 & 96.5 & 3 Jun & 6 & 2Jun & & & & $*$ & \\
\hline & 19 & 91546 & 606775 & 96 & 3 Jun & 12.5 & 2 Jun & & 18 & & & \\
\hline \multirow[t]{3}{*}{ UB } & 20 & 91552 & 606705 & 134 & $8 \mathrm{Jun}$ & 16 & 6 Jun & & & 14 & $*$ & \\
\hline & 21 & 91552 & 606706 & 127 & $8 \mathrm{Jun}$ & 9 & $6 \mathrm{Jun}$ & & 5 & & & $50 ; 90$ \\
\hline & 21 & 91553 & 606705 & 133 & 8 Jun & 7 & 6 Jun & 10 & & & & \\
\hline
\end{tabular}

Note: Asterisks in $p_{\mathrm{w}}$ column indicate that water-pressure transducers were installed in these holes.

(Fredericks Company, part No. 0717-2201) sealed and mounted within a $0.8 \mathrm{~m}$ long stainless-steel cylindrical casing. The englacial tiltmeter is suspended at any given depth within a borehole. Once the tiltmeter is fixed into the glacier, by closure of the borehole by ice deformation or refreezing, changes in tilt are analyzed to determine temporal changes in the strain rates within the glacier at different levels in the ice. At two drill sites on Haut Glacier d'Arolla (sites MA and $\mathrm{MB}$ ) englacial tiltmeters were inserted at $100 \%, 90 \%, 75 \%$ and $50 \%$ ice thickness. At the remaining sites, they were inserted at $90 \%$ and $50 \%$ ice thickness.

Tilt cells were calibrated at tilt angles $0-70^{\circ}$ from vertical. The method by which calibration functions were derived and an inversion scheme used to interpret field data is as described by Blake and others (1992, p. 391). The inversion scheme produces a discrete solution for the tilt and azimuth of the cell for each pair of voltage outputs, vl and v2. Tilt and azimuth readings change through time as the tilt cell is moved by the deformation of the ice. Azimuth of the tilt cell can change due to: (a) tilting of a near-vertical cell through the vertical plane; (b) twisting of the tilt cell about its long axis; and (c) rotation of the tilt cell about the vertical axis. The first of these types of behaviour can be easily identified by observation of a very rapid $\sim 180^{\circ}$ change in the azimuth through time. The second two causes of azimuth change cannot be differentiated. However, if it is assumed that ice deformation is unlikely to cause the tilt cell or cable to twist, then change in azimuth must be attributed to the rotation of the tilt cell about the vertical axis. This seems quite possible since the initial tilt of most cells is unlikely to be in the direction of ice flow. Thus, as the ice deforms, the tilt cell will be rotated about the vertical axis until its orientation matches that of the direction of ice flow.

It is therefore assumed that the deformation of the ice will ultimately cause the tilt cell to move such that the azimuth value will settle at a steady value representative of the flow direction of the ice. Before this occurs, "absolute" tilt values may include a significant component of tilt in a cross-flow direction that will depend on the orientation of the tilt cell in the borehole when it was first closed into the ice. Tilt values must be resolved to the flow direction. It is the rate of change of tilt in the flow direction that is required to estimate longitudinal strain rates and velocities. The procedure for estimating this was as follows.

Tilt and azimuth were plotted through time for the entire measurement period. When a steady increase in tilt coincided with very little change in azimuth over a prolonged period of time (i.e. weeks and months rather than days), then the average of the azimuth values throughout this period was taken as representative of ice-flow direction. Where no such period was evident, it was assumed that the tilt cell had not yet been orientated to the direction of ice flow. In such cases, the final value of the azimuth was taken as the best approximation of ice-flow direction. Output azimuth values were then corrected such that the azimuth value taken as the flow direction is equated to zero. Tilt angles were then resolved into ice-flow and cross-flow directions.

The error on tilt and azimuth for the englacial tilt cells was estimated by using the calibration data as input to the inversion scheme. The absolute tilt-angle error is $\pm 0.3^{\circ}$ at $0^{\circ}$ of tilt, $\pm 0.5^{\circ}$ at $30^{\circ}$ of tilt, and $\pm 0.8^{\circ}$ at $70^{\circ}$ of tilt. The azimuth error is $\pm 5^{\circ}$. The relative error between successive measurements is likely to be negligible because errors are systematic and tilt and azimuth records are generally smooth.

\section{Ploughmeters}

A ploughmeter (Fischer and Clarke, 1994) is essentially a $1.5 \mathrm{~m}$ long steel rod, the lower end of which terminates in a conical tip which is driven $\sim 0.1-0.2 \mathrm{~m}$ into subglacial sediment. The rod will bend elastically if the immersed tip is 
dragged through sediment as the glacier slides forward. Strain gauges bonded onto the rod register bending in two mutually orthogonal directions. Detailed information on the construction, calibration, installation and theory of this device is given in Fischer and Clarke (1994). Of relevance to the present study is the knowledge that, using the calibration, the bending moment as measured with the ploughmeter can be decomposed into a force applied to the tip and the azimuth of this force with respect to internal coordinates of the device.

\section{Subglacial tiltmeters}

The tiltmeters used in this study were modelled after those of Porter and Murray (2001). Like the englacial tiltmeters described above, they are built around dual-axis electrolytic tilt cells (Fredericks Company, part No. 0717-2201). Two cells, each mounted in plastic cylinders of outside dimensions $16 \mathrm{~mm}$ in diameter and $50 \mathrm{~mm}$ in length, are assembled into a string at a centre-to-centre spacing of $65 \mathrm{~mm}$. The cells are wired to flexible signal cables allowing independent movement of each cell. The lower cell is fitted to an insertion tip. Following the insertion technique of Blake and others (1992), the tiltmeter is hammered into deformable subglacial sediment at the base of a borehole. The device operates on the principle that deformation of subglacial sediments within the glacier bed will cause the angle of tilt of the cells to change.

Prior to insertion, the cells were calibrated on a special jig which allows a cell to be rotated about its long axis while the tilt of the axis is fixed at various angles. Our tilt cells were calibrated at tilt angles $0-70^{\circ}$ from vertical. Each cell has two voltage outputs from pairs of electrodes that are arranged perpendicular to each other. The calibration functions and the inversion scheme used to interpret field data are the same as used for the englacial tiltmeters, and are described in full by Blake and others (1992, p. 391). Under the assumption that the principal direction of tilt is down-glacier, the net tilt and azimuth values can be further decomposed into down-flow and cross-flow components of tilt.

\section{Water-pressure transducers}

Water-pressure transducers (IMO Industries 2000A, 016 bar) were connected to four-core guarded cable, waterproofed with resin and protected by stainless-steel enclosures. They were calibrated in the field by measuring output voltages as they were lowered at $10 \mathrm{~m}$ intervals down water-filled boreholes. Readings were measured three times at each depth as they were lowered, raised and then lowered again to the bottom of the boreholes before final deployment. Repeat voltage readings were accurate to within $0.25 \mathrm{~m}$ of water head. We assume that this value represents the relative error between water-pressure readings in any borehole. Absolute error in water-pressure readings is introduced in estimating the depth of the ice and the length of the water filled-borehole above sensors (since the borehole is not precisely vertical). The bed was considered to have been reached and hot-water drilling halted when no further progress could be made at a depth consistent with radio-echo sounding (Sharp and others, 1993) and the depth of nearby boreholes from previous field seasons (e.g. Hubbard and others, 1995), corrected for depth reduction due to negative annual mass balance. After boreholes were inclinometered, the absolute error in estimating borehole and water-pressure transducer depths was estimated as $0.5 \%$ ice thickness, that is $\sim 0.5-0.6 \mathrm{~m}$.

Water pressures are expressed as percentages of ice overburden, assuming a constant value of $916 \mathrm{~kg} \mathrm{~m}^{-3}$ for the density of glacier ice. This may be subject to a further error due to the presence of cavities and debris. Large cavities and/or rock debris prevent the successful drilling of boreholes and deployment of subglacial sensors. Although debris and cavities occasionally affected drilling rates, they were not considered a significant source of error in estimating ice density at this glacier since the bed was reached repeatedly at all sites.

\section{Instrument deployment in subglacial sediment}

Deployment of instrumentation into subglacial sediment suffers from the uncertainty about the precise position of the instrument with respect to the ice-bed interface, not least because of its expected complexity. Subglacial sediment may squeeze upwards into the bottom of boreholes. In this case, sensors, though inserted in the sediment, are potentially installed within the body of the glacier. We believe that this possibility can be ruled out since the shear-deformation rates implied by the tiltmeter measurements exceed the ice-deformation rates that would control sediment deformation within an ice-walled hole. Equally, the force recorded by the ploughmeter can only be explained by its tip being inserted into basal sediment below the icebed interface. Another difficulty arises from the hydraulic excavation by the hot-water drill which is believed to loosen subglacial material to a depth of several decimeters below the ice-bed interface (Blake and others, 1992). It is therefore likely that an instrument, once lowered to the bottom of the borehole, settles into this disturbed layer simply by its own weight. However, based on our experience with inserting instruments using the same procedure (Blake and others, 1992; Fischer and Clarke, 1994), we believe that we are able to constrain insertion depths to within $\pm 30 \mathrm{~mm}$.

\section{Meteorology and proglacial stream discharge}

Meteorological data were obtained from a weather station maintained by the hydroelectric-power company Grande Dixence SA (GDSA) located at an altitude similar to that of the snout of Haut Glacier d'Arolla but $10 \mathrm{~km}$ away at Bricola (Fig. 1). Proglacial stream discharge was measured every hour by GDSA at an intake structure located $\sim 1 \mathrm{~km}$ from the glacier snout. 